\title{
The Peri-Tethys Programme: achievements and results
}

\author{
1 Dipartimento di Scienze della Terra, Università di Milano, Via Mangiagalli 34, 20133 Milano, Italy. \\ 2 Départment de Géologie Sédimentaire, Université Pierre et Marie Curie, Paris VI, pl. Jussieu 4, F- 75232 PARIS, Cedex 05, France.
}

\begin{abstract}
The results of the Peri-Tethys Programme are summarized. Hundreds of scientists were involved, producing several hundred papers and congress presentations. Six memoirs, and six special issues were published in International Journals or are in press. The major cooperative product is the Atlas with 24 paleogeographic maps. Main highlights of the Atlas and its Explanatory Notes are addressed in this paper.
\end{abstract}

\section{Introduction}

The Peri-Tethys Programme concluded its activity with the final Meeting held in Paris on November 23-24, 2000, and the publication of the $6^{\text {th }}$ volume of the Memoirs (December 2001). Proposed in 1993, the Programme has been sponsored by oil companies (here listed before recent mergings: Agip, Arco, Chevron, Conoco, Elf, Exxon, Shell, Sonatrach, Total), by French research agencies (IFP, BRGM, CNRS) and by the University PM Curie (Paris VI). Important results were already submitted to the sponsors in Orleans, in July 1999 , and after one year of confidentiality, the results were distributed and available to the public.

The basic question of the Programme was: how did the areas with continental lithosphere, lying to the north and to the south of the Tethys, react to the evolution of this ocean with its different branches, as well as to the evolution of the Central Atlantic, during the long span of time from Carboniferous to Pleistocene? How did the environments on the platforms bordering the Tethys evolve? Many geodynamic events took place. The seaways of the Tethys opened and closed between the two broad regions that formed its northern and southern borders. Of major importance were also the final stages of the Variscan orogeny and obviously the Alpine orogeny that took place during the time considered. The starting point was provided by the results of the Tethys Project lead by J. Dercourt and L.E. Ricou, which ended in the early nineties (Dercourt et al., 1993). In particular, the geodynamic setting and kinematics resulting from that programme were adopted as the basis to analyse their effect on the marginal areas. In comparison to the Tethys project, the area of interest was reduced from the Atlantic to the Urals and the Aral Lake to the north, and from Morocco to the Gulf to the south (Figure 1).

The Peri-Tethys Programme had several goals. The first goal was to obtain a brand new palaeogeographic and palaeonvirinonmental set of maps. To obtain this first of all we tried to update the stratigraphic and structural information on central and eastern Europe, as well as all along the African and Near and Middle East regions. The new political trends in Eastern Europe encouraged us to focus on that area and gather from local scientists a brand new set of information obtained through new research by local or international teams. In the first 3 years of the Programme we made a very large "Call for Proposals". One hundred and seventy two were accepted and funded (114 in the north and 58 in the south). Annual meetings were held in Arles, Paris, Milano, Amsterdam, and Rabat. Papers presented at those meetings or originating from research sponsored by the Programme were collected in twelve special volumes. Six Peri-Tethys Memoirs were issued as Memoires of the Museum National d'Histoire Naturelle, Paris, three as Special Issues of the journal Geodiversitas, and recently, three special volumes of Elsevier Journals were published (see reference list). In addition, hundreds of scientific papers, dealing with the results of research sponsored by the programme, have been published in international journals and more are still to be published.

\section{The Peri-Tethys Atlas}

The main objective of the Programme was to prepare a Peri-Tethys Atlas on the scale 1:10,000,000. It contains a set of 24 maps, from the Moscovian to the latest Pleistocene, encompassing a time span of $300 \mathrm{MY}$. The basic idea in producing the maps was to deal with a time slice as short as possible in order to have a kind of a snapshot. The ideal was to restrict the map time to no longer than 2 MY, even if for older maps this goal is largely impossible. This choice has several consequences:

1) It requires very accurate correlations. In marginal or continental areas correlations might be feeble. Accuracy is consequently feeble and the actual presence of the recorded environment is only tentative.

2) To obtain better correlations the selection of time slices privileged high-standing times of the sea level. This choice may obscure how extended the emersions were during low-standing times. However, this choice was necessary for the sake of correlation and the availability of data.

3) To correlate it is necessary to have a record through the sediments. Therefore the choice of the time slices privileged the transgressive tracts of the sequences. However, this choice may give the wrong impression of a talassocratic regime as the average regime, which was not necessarily the case.

4) Time intervals between maps vary from 15 to $30 \mathrm{MY}$. Tectonic events may occur in between two subsequent maps and could not be recorded. On the contrary, a tectonic event may be lasting for a long interval, but cannot be perfectly constrained within the selected time slice. The choice was to represent it anyway.

The maps are the result of a very wide effort of hundreds of scientists from Europe, Africa and Asia. The first step in the process of producing the maps relied on paleonvironments and paleogeography, which were under the responsibility of 6 map leaders, G. B. Vai (Moscovian-Artinskian), M. Gaetani (Wordian to Norian), J. Thierry (Sinemurian to Tithonian), J. Philip (Hauterivian to Maastrichtian), J. Meulenkamp (Ypresian to Piacenzian) and J-P. Peulvast (Pleistocene). Each map leader organized regional work-groups and in some instances he decided to share the responsibility for single maps with others. Each map leader discussed the results of the regional work- groups with the scientists involved over several meetings, held in many localities. As a result of this process, the map leader(s) prepared the final version of the map, trying to unify the facies pattern in a coherent view. 


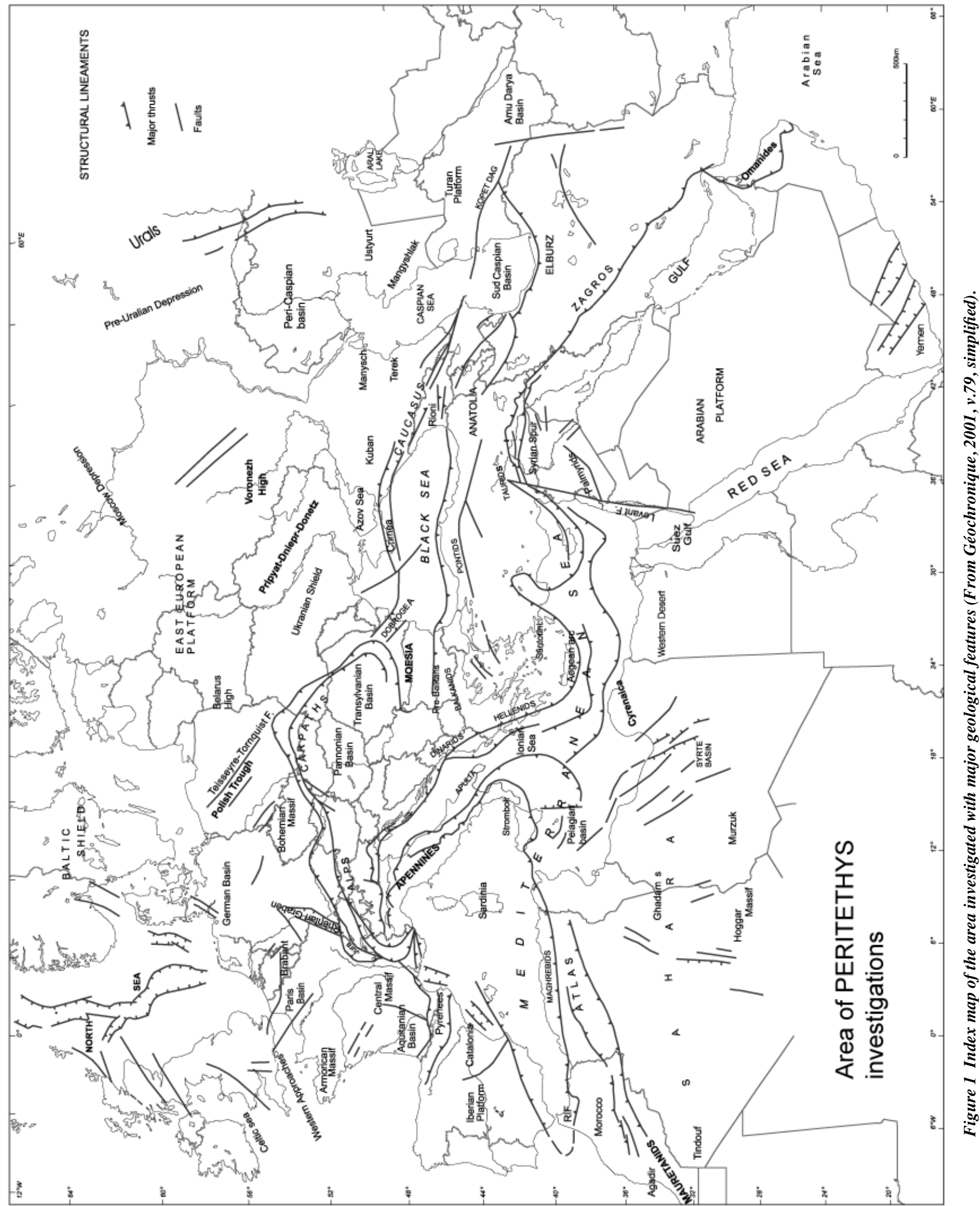


A similar process was undertaken for the structural part, which was lead by E. Barrier \& J. P. Cadet for all the maps. They added to the maps the tectonic data, with the help of regional experts, on the basis of the draft already produced for paleoenvironments and paleogeography, in some case providing also some paleotectonic information. Additional data for the subsiding basins were supplied by scientists involved in the modelling sub-project, as well as the paleostress data provided by the paleo-stress research group.

The set of maps is supplemented with a volume of almost 300 pages of Explanatory Notes (coordinated by S. Crasquin) dealing with the main characteristics, region by region, for each map.

The drawing of the maps was done on a palaeogeographic setting derived mostly from Ricou's $(1993,1996)$ kinematics, with changes concerning Iberia, Moesia and Anatolia. B. Vrielynck, who was in charge of all the informatics at the University PM Curie in Paris, provided the basis for the drawings. Since it was decided to start from the geodynamic reconstructions of the Tethys Project (Dercourt et al., 1993), the first step was to transform the oblique rectilinear projection into a rectilinear projection. All maps are digitalized with the Arc-Info software. Since the Tethys Project prepared only 14 maps, from Late Permian to Tortonian, and from the beginning it was decided not to carry out new research in the Tethys realm, in 5 out of 10 new maps the Tethys sector remains underrepresented. On the contrary, in 3 of the maps of the Peri-Tethys Programme the Tethys area is considered (Moscovian, Artinskian and Sinemurian). The Olenekian is represented only for the northern Peri-Tethys and the Late Pleistocene map obviously may adopt the present-day configuration.

The 300 Ma period may be subdivided in three major intervals that we might define as the Pangea Time, the Tethys Time and the Alpine Time. The Pangea Time includes the interval from the Moscovian to the Middle Triassic, the Tethys Time spans the interval from Late Triassic to the mid Cretaceous, and the Alpine Time addresses the more recent interval.

\section{The Pangea time (map 1-Moscovian to map 5-Early Ladinian)}

This interval, about $100 \mathrm{MY}$ long, is mostly a time of convergence, important lateral displacements and oblique rifting. A number of basic features may be recognised:

- the final assembling of Pangea, including the closure of the Ural seaway and the final building of the Ural Mountain Range;

- the ongoing subduction of the Paleo-Tethys below the Eurasian margin with the formation of the Altaid Orogenic system and the subsequent consolidation of the Turan block;

- the opening of the Neo-Tethys with the transit of the Peri-Gondwanan fringe blocks from Gondwana towards Eurasia and their final welding against the northern continent;

- the large lateral displacements between Africa and Eurasia, with local transtensions, pull-apart basin opening and transpressions.

Resulting from these major kinematic trends, the Peri-Tethyan regions were largely under continental conditions during the Pangea Time, independently from the dominating glacioeustatic low-standing during the Late Carboniferous and earliest Permian, which is only marginally reflected in the Moscovian map. The Moscovian was an interval of relative high-standing of the sea level.

\section{Palaeonvironments and sedimentary environments}

A large variety of environments is shown on the maps due to the significant climatic and sea level changes, relief formation and erosion, and frequent low sea level standing during the Pangea Time.
Because of the Hercynian orogeny in Europe, the formation of Mauretanides and Appalachians and of the Ural-Altaid orogenic system, several mountain ranges bounded the Peri-Tethyan regions or were uplifted within the Peri-Tethyan regions, supplying and feeding a large amount of debris to the fore deep, piggy back, back arc or retro arc basins. Consequently, fluviatile and lacustrine deposits were very widespread. When the coastal relief was or became gentler because of progressive flattening during the Permian and the Triassic, important interfingering with the marginal brackish seas developed over very wide flats. The most typical is the flat of Arabia towards the Neo-Tethys, which was about $1000 \mathrm{~km}$ wide. Along the shores of the Tethys epicontinental seas extended over not very deep floors, sometimes as wide as $1000 \mathrm{~km}$ like the Mid-European Basin and the Peri-Caspian Basin during the Middle Triassic.

The climate evolved from the severe gradients of the Moscovian, when wet forests flourished in the Eurasian belt, and glaciogenic deposits formed in Oman, to the increasingly arid weather of the Permian and eventually to the arid/semiarid climate of the Triassic. Consequently, playa deposits filled the continental basins as well. In particular conditions, often in time slices not represented by the maps, huge salt deposits, periodically fed by the neighbouring shallow seas, filled up the depressions. The Kungurian salts of the Precaspian Depression, the post-Wordian Zechstein in the Polish Trough, German and North Sea basins, the Bellerophon basin in the Southern Alps and the Khuff Member B to D in the Arabic peninsula are examples of such enormous subtractions of salts from sea water.

In the epicontinental seas, algal and coral assemblages were able to build significant carbonate banks, in which fusulinids, brachiopods and other invertebrates dwelled. After the Permo/Triassic crisis, since the Middle Triassic, the "carbonate factory" was fully at work. Most of the marginal seas were in low-temperate to equatorial conditions, and consequently carbonate banks and ramps were widespread.

\section{Structural evolution}

The kinematics of the Pangea Time is presently a matter for lively discussion. In particular, disagreements exist in the literature on:

A) The relative position of Gondwana and Laurasia at the end of the Variscan Orogeny in the Carboniferous.

B) Timing and modality of rifting and northward motion of the periGondwanan Cimmerian terranes in the Permian-Triassic.

For point A) there are two major interpretations:

1) According to the majority of the authors (e.g., Stampfli, 2000; Scotese and McKerrow, 1990; Ziegler, 1983), Gondwana and Laurasia remained fixed with respect to one another in a Pangea A configuration for ca. $200 \mathrm{Ma}$ from the Carboniferous to the Jurassic.

2) Significant dextral shear developed between Laurasia and Gondwana (Figure 2). Irving (1977), Morel \& Irving (1981) and Torq et al. (1997) suggested that Gondwana and Laurasia were arranged in a Pangea B configuration during Carboniferous to Permian times. Pangea B differs from the standard Wegenerian Pangea A in that South America is placed south of Europe, and Africa, attached to South America, is located south of Asia. In other words, in a Pangea B configuration Gondwana is shifted to the east with respect to Laurasia by at least $3000 \mathrm{~km}$. The transformation from Pangea B to Pangea A must have occurred sometime between the end of the Variscan Orogeny and the beginning of the opening of the Atlantic Ocean in the Jurassic, because it is well known that the Atlantic opened from a Pangea A configuration.

According to Irving (1977), Morel \& Irving (1981) and Torq et al. (1997), the transformation from Pangea B to Pangea A occurred essentially in the Triassic, whereas Muttoni et al. (1996) suggested that the transformation occurred essentially during the Permian and represents the final stages of the Variscan Orogeny. 


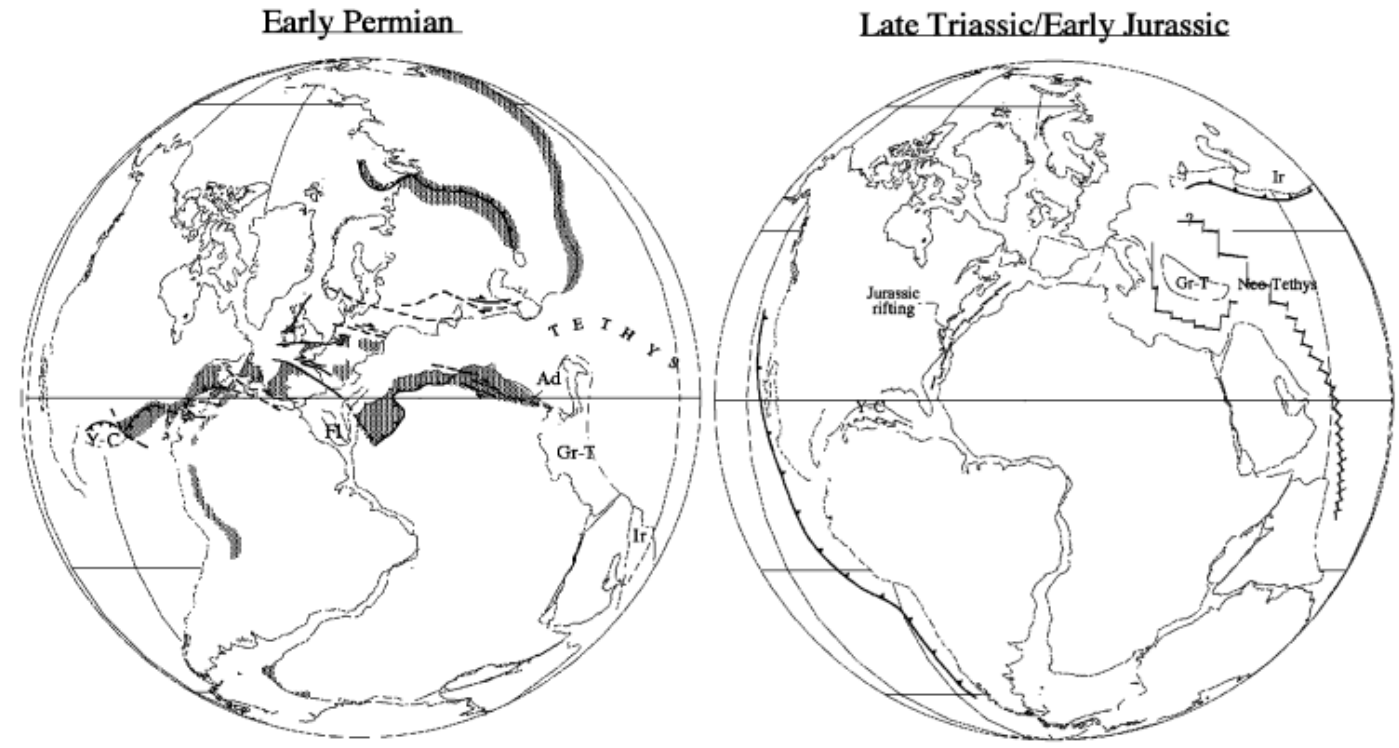

Figure 2 Simplified Pangea configurations, illustrating the dextral shearing of Laurasia vs. Gondwana from Early Permian to Triassic (Courtesy of G. Muttoni, 2002).

In the Peri-Tethys maps the interpretation of a lateral dextral displacement between Gondwana and Laurasia was adopted. Starting from the configuration of the first map in the Tethys Atlas (Murgabian) (Dercourt et al., 1993), the two major continental land masses were displaced back to the Moscovian time for an additional $400 \mathrm{~km}$, resulting in a configuration intermediate between the two discussed previously.

As far as the rifting of the Cimmerian terranes is concerned (Point B), a general consensus was reached in the scientific community that these terranes originated by means of Neotethyan rifting along the northern margin of Gondwana (e.g., Transit Plate model of Ricou, 1996). However, some disagreements still exist on the exact timing of the rifting (now considered as old as the Carboniferous) as well as on the terranes lateral contiguity and configuration during their northward migration across the Paleo-Tethys. In particular, Neotethyan rifting of Carboniferous age characterizes the Gondwanan margin of Himalaya (Garzanti et al., 1996) and Karakorum (Angiolini et al., 2001). Towards the northwest, along the Gondwanan margin of Oman, Neotethyan rifting occurred in the Late Carboniferous (Al Belushi, 1996; Angiolini et al., 2001), whilst the spreading started later in the Early Permian (Angiolini, 2001). More to the northwest, at the western end of the Tethys Ocean, contrasting opinions on the origin of the Ionian and the eastern Mediterranean oceanic basins complicate this tectonic scenario. According to Vai et al. (2000), Stampfli (2000) and Stampfli et al. (2001), the Ionian basin represents the western end of the Permian Neotethys Ocean. Gaetani et al. (2000) and Catalano et al. (2001) propose instead that the Ionian basin is a seaway on continental crust at Permian times, whereas true Neo-Tethyan oceanic crust is Triassic in age and located more to the north between Moesia and "Adria" (i.e., the Vardar Ocean).

Keeping in mind the assumed configuration, the palaeogeographic reconstructions are made complex by the interplay of three main trends:

- to the east, the continuous activity of the Transit Plate (Ricou, 1993, 1996) was the driving mechanism in the subduction of the Turkestan oceanic lithosphere during the Carboniferous and Early Permian and, later, of the Paleo-Tethys oceanic lithosphere underneath the Asian margin. The rotation of the Transit Plate was also the mechanism triggering the opening of the NeoTethys Ocean during the Permian, between the Peri-Gondwanan fringe blocks and the India and the Arabia parts of Gondwana. The continental blocks involved were progressively accreted to the Asian margin, originating volcanic arcs and back arc basins in the Caucasus-Caspian-Turan regions (Garzanti \& Gaetani, 2002).

- The northwestward rotation of Godwana against Laurussia, with the progressively heterochronous collision during the Carboniferous and the Early Permian, led to the formation of the Mauretanides and the Appalachians, amongst others. The lateral displacement involved was dextral (Matte, 1986). Most intriguing is the time span from Middle Permian to Middle Triassic, roughly from 270 to $230 \mathrm{Ma}$ (Figure 3). During this interval the convergence was gradually over and thermal and gravity relaxation affected the mountain areas, with local rifting, transtention and transpression. In this situation the Neo-Tethys showed trends to propagate westwards, dissecting part of the convergent zone in the future southern Europe. The result is a complicate paleogeographic pattern, not yet properly understood. Pop-ups of mantle serpentinite slices were detected in the NW Caucasus during the Early Triassic, evidencing the importance of transpressional movements (Gaetani et al., 2003). This trend ended in the Carnian (Late Triassic), when progressively propagating rifting from the future central Atlantic Ocean inverted the movements between Gondwana and Laurasia in a senestral direction. The pivot time, Carnian, is very well constrained, both on the Moroccan (Courel et al., 1999) and on the North American sides (Olsen et al., 1999; Kent et al., 1995), eventually leading to the onset of the great Central Atlantic Magmatic Province (Olsen, 1999; Marzoli et al., 1999).

- After the collision and building of the Variscan orogen, Northwestern Europe underwent a horst and graben evolution, partly with a significant N-S component, and partly with a NW-SE component. This is the result of the orogenic collapse following the acme of the convergence, of the ripercussion of the rifting trend active in the area of the future North Atlantic, and of the different displacement speeds between the Baltic Shield and East European Platform on one side and the Western-Central Europe on the other side, along the Tornquist-Teyssere alignment.

\section{Magmatism}

During the Pangea Time magmatism was very widespread in the orogens, but volcanic rocks are frequent also outside the main orogenic belts, and are largely of calk-alcaline signature. Volcanoclastic products are preserved mainly in the Turan, Altaid and Pre-Uralian depression, and their composition varies from andesitic to dacitic and ryolitic. 


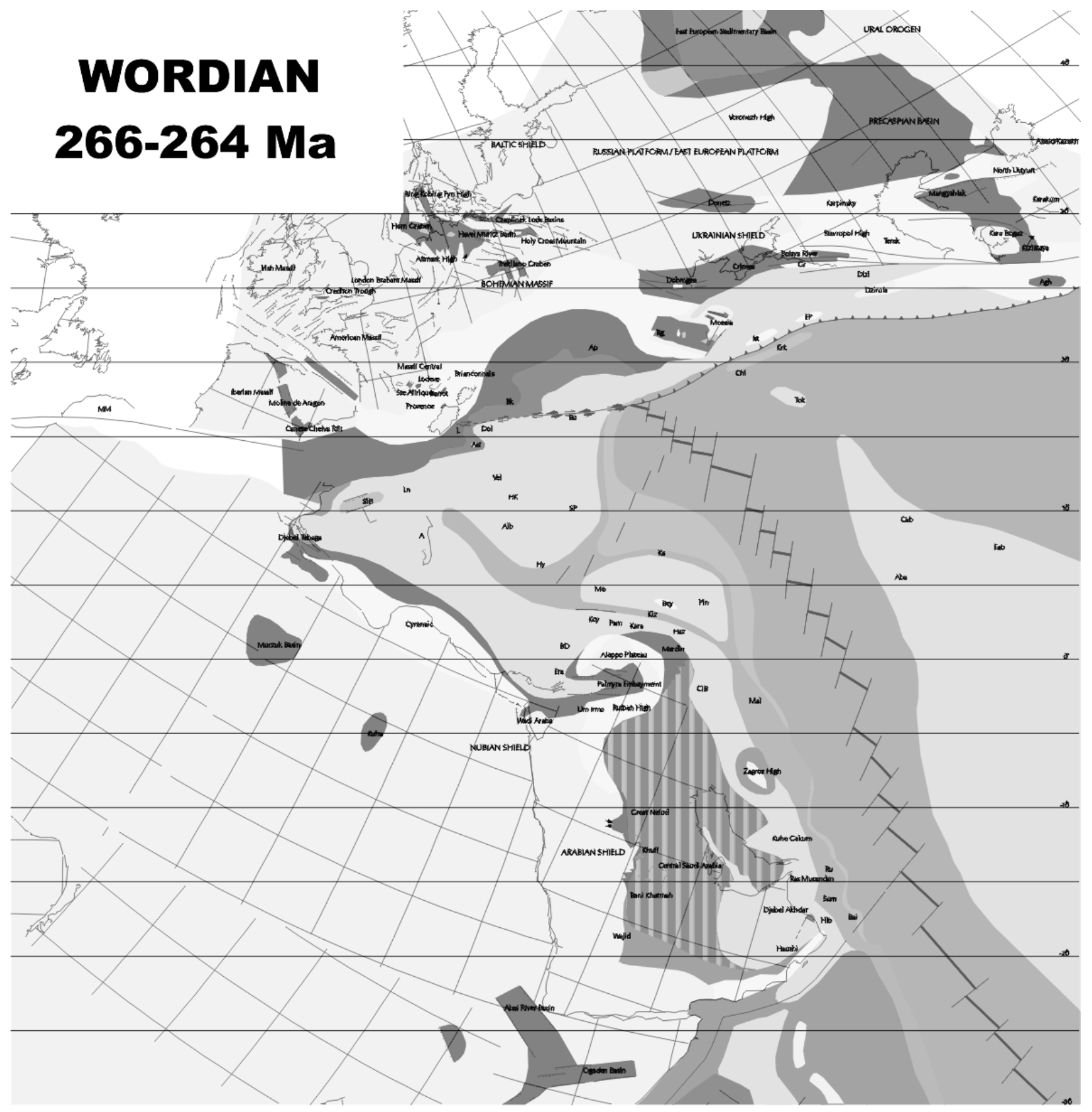

Unknown, not interpreted

Exposed land - Non-deposition : assumed

Exposed land - Non-deposition: ascertained

Eolian

Fluviatile, lacustrine, fluvio-lacustrine

Glacial and fluvio-glacial

Shallow environments with fluctuating salinities

(from freshwater/lacustrine through brackish and

shallow marine to hypersaline)

Deep environments with salinities deviating from normal

("brackish marine")
Coastal marine, shallow marine (terrigenous-clastic)

Deep marine (bathyal-abyssal)

Marine carbonate build-ups; platform carbonates

Deep(er) carbonates, (hemi)pelagic oozes

Hypersaline

Deep oceanic basins

Volcanics - A : alkaline, C : calcalkaline

Island arc

Figure 3 Simplified paleogeographic map of the Wordian time. All maps are simplified from the Peri-Tethys Atlas (Dercourt et al., 2000). 
In the Caucasus, Dobrogea and the entire Western Europe bimodal volcanics are particularly widespread during the Permian, linked to the transtensive and transpressive lineaments. Bimodal volcanism is present also during the Triassic, but it is concentrated more within the branches of the Tethys than on the Peri-Tethyan regions.

\section{Tethys times (Map 6-Late Norian to Map 13-Early Aptian)}

The Tethys Time interval from Late Triassic to Early Cretaceous, about 120 Ma long, was mostly a time of extension in the area considered. Particularly, the Pangea suffers extension between the "Tornquist-Teisseyre line" and a "North African line" (Norian, Sinemurian, Toarcian) (Figure 4). In this domain the extension reaches the oceanic stage (Callovian) (Figure 5) and generates a multi-plate structure with complex kinematics and a sill between the eastern Neo-Tethys and Central Atlantic oceans (the Mediterranean Seuil; Vrielynck et al., 1996). Since the Gondwana break-up was heterochronous, eventually the Cimmerian blocks collided with Asia within the Liassic times. Both the Atlantic and proto-Indian oceans are synchronous with the complex net of oceanic and thinned crust basins in the Mediterranean Seuil. Due to the opening of the South Atlantic, the anti-clockwise rotation of Africa during the Early Cretaceous gradually introduced a convergence setting along most of the Tethyan area, beyond the already active margin from Pontides to Caucasus, resulting in island arc volcanic complexes and back-arc extensional basins, like the Kuban and Terek basins. The significant rising of sea level caused large ingressions on the marginal basins of the Peri-Tethys. On the northern side, during the Early Jurassic, large areas of Western Europe were inundated, establishing a connection between Boreal and Tethyan waters. By the Middle Jurassic also the connection between the Barents-Petchora and the Tethys was opened along what was the former fore-deep of the Urals and the Caspian-Aral area. Europe was mostly a sea, punctuated by large and small islands, the larger being the Fennoscandian Shield.

The strong asymmetry between the Mediterranean and the Arabian-Somali sides of the African continent persisted on the southern shore of the Tethys. The epicontinental platform and the marginal basins were small or transtentional to the north, linked to the opening of the Ligurian ocean and its connection to the Central Atlantic Ocean. Instead, on the eastern side of the African continent wide inundated areas produced epicontinental ramp carbonates, evaporitic and marginal clastic deposits.

\section{Palaeoenvironments and sedimentary environments}

The environments were relatively stable during this period and depended mainly upon global factors, both kinematical and biological:

1. The opening of a seaway allowing water transit from Eastern Tethys and Panthalassa to Western Tethys and Panthalassa. This east-west seaway has no present-day equivalent at the same latitudes (Dercourt et al., 1993);

2. The northward drifting of the entire complex of the Eurasia and Africa plates shifted the regions of the northern Peri-Tethyan belt, largely in tropical position during the Triassic, to temperate

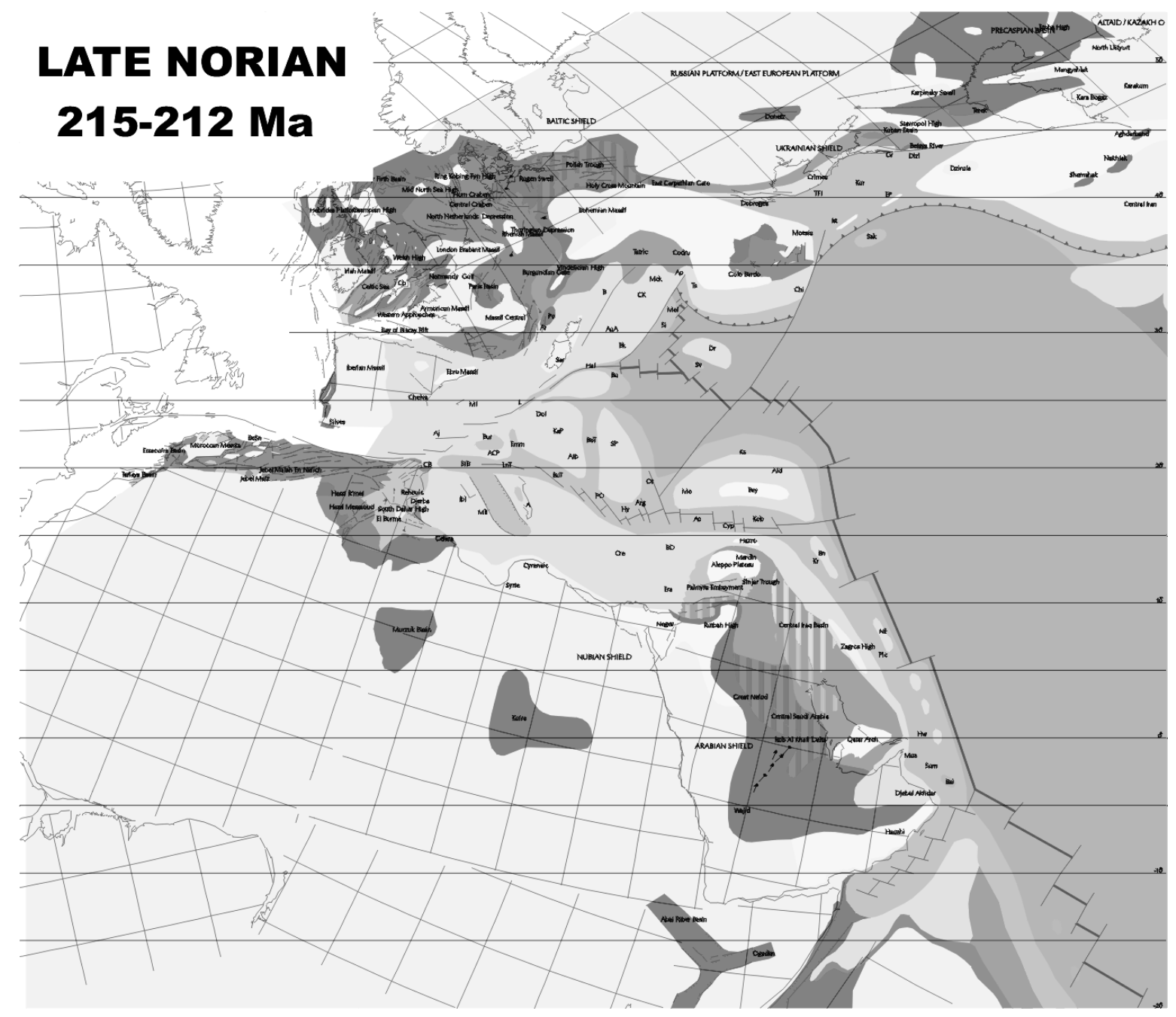

Figure 4 Simplified paleogeographic map of late Norian time. 
conditions, resulting in a wetter climate. The region to the south, now at tropical and equatorial latitudes but leeward of a very large continental mass, was under prevailing arid and semi-arid conditions, accounting for the wide evaporitic deposits largely diffused in Arabia, Egypt, Libya and Maghreb at different time during the Jurassic.

3. The changes in palaeoenvironment are dependent mainly on transgression / regression regimes, like:

- river level equilibrium;

- water evaporation, very sensitive in this equatorial region (critical for greenhouse effects);

- rate of spreading and correlative volcanic effects and water chemical composition (hydrothermalism);
4. Sediments accumulated during Tethyan Times are basically bioorganic or with an important organic content and, therefore, dependant on the living species (corals, algae, microplanktonic organisms contained in marine oozes, continental living organisms), stressing the importance of biology as a key environmental factor.

Four main sedimentary environments were identified:

1. Emerged land and marshes

The deeply eroded craton feeds clastic sedimentation on the emerged land and on transitory emergent carbonate platform bauxitogenesis takes place at suitable latitudes.

- On the northern Peri-Tethyan platform mountain range erosion rules the sedimentary activity. Significant sediment suppliers are

\section{MIDDLE CALLOVIAN \\ 157-155 Ma}

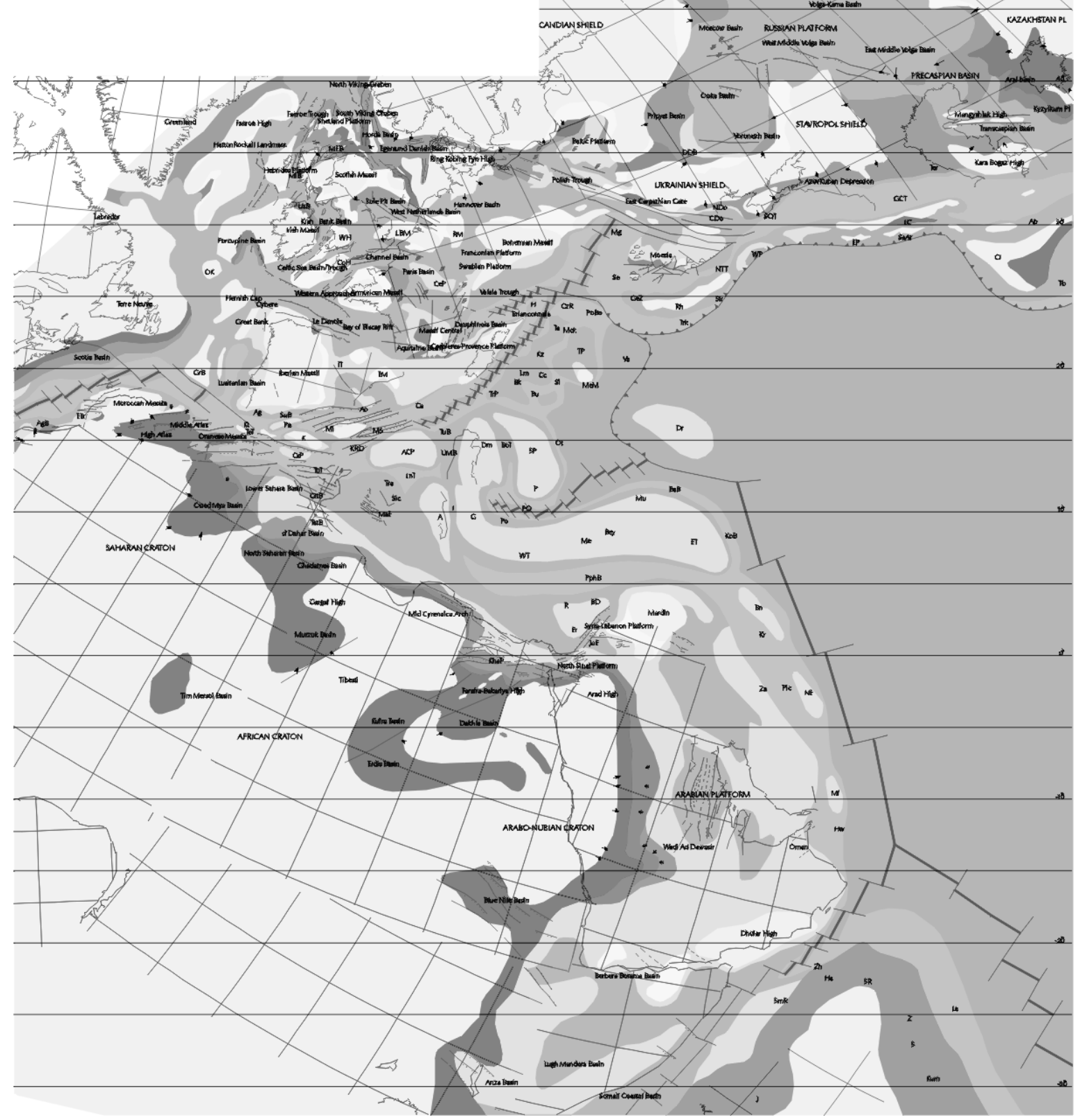

Figure 5 Simplified paleogeographic map of middle Callovian time. 
(i) the Variscan (Norian to Toarcian), (ii) Uralian (Norian to Toarcian) and (iii) Cimmerian orogens (since Liassic times).

- On the southern Peri-Tethyan platform the African craton tends to be a significant supplier, more productive than the northern craton, in endoreic, fluviatile and deltaic basins. Age determination is poorly established in continental clastics and the attribution to one map or another is poorly documented as well. Granulometry and volume of clasts are directly related to sea level. Clasts are coarser and abundant in regressive times (Norian-Sinemurian, Tithonian-Hauterivian, Aptian), fine grained and relatively rare during transgressions (Callovian and Cenomanian).

- At the periphery of the continents, in the proximity of the sea, terrigenous clastic sediments located in equatorial zones $\left(15^{\circ} \mathrm{N}\right.$ and $15^{\circ} \mathrm{S}$ latitude) provide fine clasts in shallow environments subject to episodic invasions of seawater and inter-fingered with sediments deposited in areas with fluctuating salinity.

- In appropriate areas, bauxites accumulate mainly in karsts. Some alterites are also to be found on recently obducted ophiolites (Aptian). The main phase for bauxite formation corresponds to the most important transgression.

\section{Epicontinental deposits}

On cratonic basements under tropical and subtropical climatic zones, mainly terrigenous coastal deposits are interbedded with evaporites which concentrate substantially in equatorial climatic zones $\left(15^{\circ} \mathrm{N}\right.$ or $\left.15^{\circ} \mathrm{S}\right)$, e.g., Sinemurian, Toarcian, Kimmeridgian, Tithonian).

As for the main clastic production, carbonate composition prevails in deposits where fossils species are scarce but individual organisms abundant.

In permanent marine domains shallow water carbonate platforms are covered by limestone, frequently dolomitised. They define supratidal to shallow sub-tidal environments. Ramp carbonate platforms develop from shallow to deeper environments. They are widespread at all latitudes. Shelf edges in inter-tropical climatic zones can be fringed by reefal build-ups presenting a high diversity of organisms. At the beginning of the Tethys Time in the Late Triassic, peculiar geochemical conditions of the sea waters resulted in the formation of the extremely wide carbonate platform from the Betic margin to the Peri-Gondwanan Fringe and Oman, which was subsequently penecontemporaneously dolomitised

Pelagic limestones (nannofossil oozes) are associated with minor siliceous tests (sponges, radiolarians), including siliceous nodules. They are locally iron and manganese enriched, their location being mainly under tectonic control (e.g., Rosso Ammonitico). Pelagic marls with rhythmic sedimentation (astronomically controlled?) cover epicontinental basins and talus. They are supposed to accumulate as deep as $1000 \mathrm{~m}$, shallower than most black shales. These organic black shales of lacustrine or marine origin concentrated in anoxic to mildly oxic basins and are potential source rock for hydrocarbons (Toarcian, Callovian-Kimmeridgian, Aptian, Cenomanian).

\section{Deep basin (in part oceanic) deposits}

The pelagic marls may be deposited also in deep basins, even in oceanic basins above the CCD. Most radiolarites, even if some are sedimented in epicontinental environments, are located below CCD. They are time dependant and the peak deposition is during the Kimmeridgian.

\section{Active subduction environments}

The marginal seas involved in this geodynamic setting show the same sedimentary signals of the passive margins presented above, except for the deposits associated with the subduction itself. Here, the main deposits are turbidites (they are not exclusive of active margins since they exist on distal parts of the talus and on the margins of rapid subsiding intra-cratonic areas) and are always present whenever subduction occurs.

These sequences are frequently siliceous argillites alternating with siliceous calcilutites showing a graded bedding both vertically and horizontally. The deposits include olistoliths and oceanic remnants (ophiolitic blocks); they are rich in volcanoclasts and are interfingered with lava flows and intruded by micro-gabbros or microdacites. In Tethyan times, they are frequent in the South Caspian, Caucasus and Dobrogea.

\section{Structural evolution}

The kinematics in Tethyan Times are simple: extension with predominant crustal thinning between the Tornquist-Teisseyre and North African lines. No special attention was given in the Atlas to the future Alpine chain, and the Tethys reconstruction (Dercourt $e t$ $a l ., 1993$ ) was modified only when necessary. In the western Tethys many extensional features, like the west-facing escarpment of the Central Apennine platform, reactivated later as the Ancona-Anzio Fault, were not shown. Also in the Balearic area no tectonic features were indicated to explain the approaching of Sardinia and Catalonia at the closing of the Tethys Time. The Turkish and Hellenic areas were addressed sketchily as well, since it was not a direct concern of this Atlas.

Nevertheless, it is worth to mention the behaviour of the permanent subducted domain to the south of the East European craton. To the east, the Cimmerian blocks completed their accretion to the Turan and Scythian Plates in the Early Jurassic. However, later in Aptian times, an island arc appeared, as well as marginal seas that separate the Cimmerian blocks by thinned or oceanic crust, while the main subduction migrates from north to south.

In Tithonian times part of the Neo-Tethys obducted on microcratons of the Mediterranean Seuil and ophiolites cropped out and flysch soon accumulated (e.g., Bosnian flysch).

The Cenomanian marks a complete structural change (Figure 6). From this time onwards the Alpine Time starts and is related to the counter-clockwise rotation of the newly established African plate.

\section{Magmatism}

The tholeiitic basalts of the Central Atlantic Magmatic province, probably the largest Large Igneous Province known to date on the

\section{Ages in $\mathrm{Ma}$}

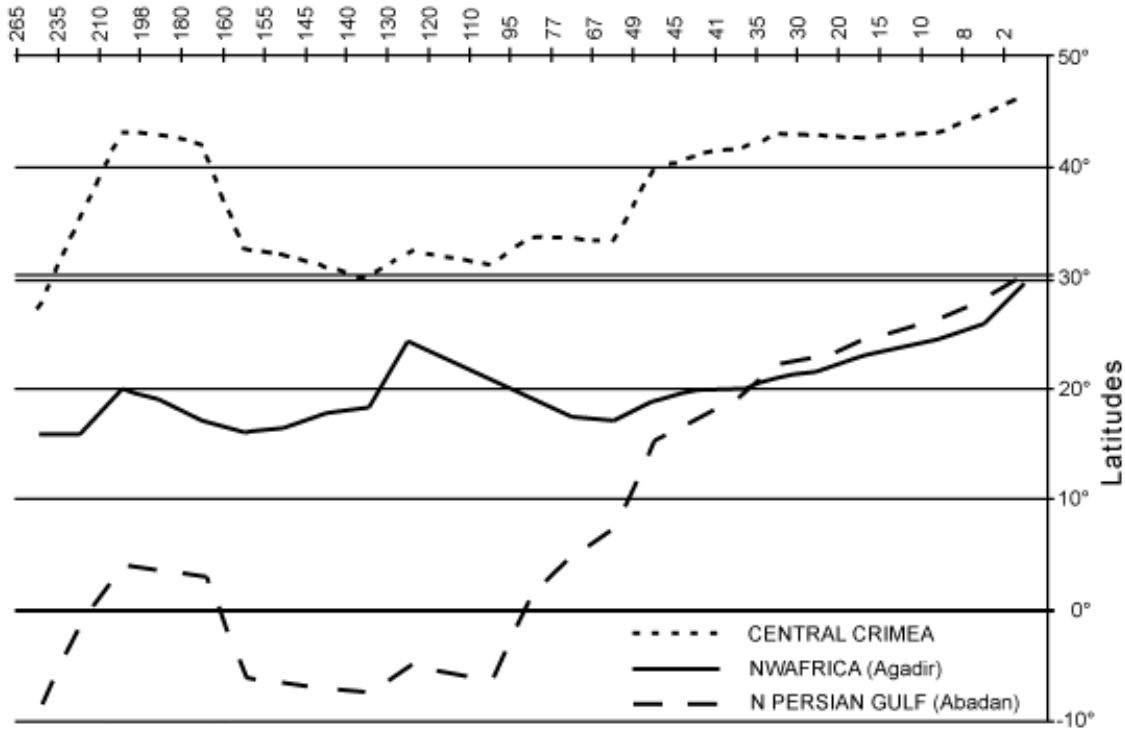

Figure 6 Latitudinal shift of Crimea, NW Africa (Agadir) and Northern part of the Gulf (Abadan) from 265 Ma to Present (From Dercourt, Gaetani \& Vrielynck, 2000). 
planet (Olsen, 1999), are connected with the beginning of the divergence that will give way to the opening of the Central Atlantic. Associated with this major event is the intracratonic magmatism related to the crustal thinning in Late Triassic-Liassic times all over the domains (e.g., West Europe, West Africa, North Sea during Middle Jurassic). The volcanism of island volcanic arcs and the opening of marginal seas associated with subduction in the present-day Caucasian-Dobrogea and Black Sea areas (Sinemurian, Toarcian, Callovian, Kimmeridgian) are represented as well.

\section{The Alpine time (Map 14-Cenomanian to map 24-Pleistocene)}

This 95 Ma long interval, the Alpine Time, is the more recent interval, mostly a time of convergence and inversion. The premium motus in Alpine times is the opening of the South Atlantic Ocean and the individualization of the Africa-Arabia plate with its counterclockwise displacement. Therefore, palaeomagnetic data evidence a major northward displacement of the eastern part of the plate, and a minor movement of the western side.

The Alpine Time could be subdivided in two periods. The first was during the Cretaceous, when the convergence progressively involved most of the European side, with the onsetting of the Eoalpine orogeny. The marine links between North Sea and Western Europe basins and the East European Platform basins along the Polish Through were repeatedly interrupted. Only the world-wide maximum high-standing of the sea level restored these communications. The northward extension of the Atlantic accretion ridge gave origin to the short-living Biscay ocean between France and Iberia (see Aptian to Lutetian maps). To the south, geodynamic activity in the Mediterranean, with a latest transit-plate (Tauric plate) (Ricou, 1993) migrates from Africa-Arabia to the north in relation to a spreading oceanic ridge (Pamphylian basin) in the west. To be noted also the onsetting of subduction inside the micro-plates forming the Mediterranean Seuil. New basins became deeply entrenched into the African margin, in Tunisia, Libya and Egypt, where the high-standing of the mid Cretaceous time also allowed wide marine ingressions onto the African land.

The second sub-period, during the Cenozoic, was dominated by convergence and a progressive continent/continent collision of mountain ranges (Pyrenees, Alps, Carpathian, Dinarides, Balkan, Pontides, Taurides, Maghrebides, then Zagros). A general inversion of pre-existing faults inside both Peri-Tethyan platforms develops as well, creating an east-west prevailing structure (basins and heights) instead of the previously scattered directions. The northern PeriTethyan areas were progressively cut off from the marine connections to the south and the Peri-Tethyan basins of western and central Europe were inverted from the Oligocene onwards. In Eastern Europe extensional basins opened in back arc settings, some with thinning of crust up to oceanisation, like the Black Sea sub basins. Peculiar and widespread anoxic facies developed, linked to high organic productivity.

The convergence regime induced a progressive inversion of several basins also to the south. From the Oligocene, extensive volcanic activity lined the rifting and subsequent opening of the Red Sea. The collision of the Syrian Spur against Anatolia eventually closed W-E marine connections along the Tethys, further fragmenting the possible connections between the marginal basins.

\section{Palaeoenvironments and main sedimentary environments}

The environments change drastically from Tethyan Time, during which biogenic sedimentation prevailed, to Alpine Time when clastic deposition took over, with the following results:
1. the cratons become less important clastic suppliers (the break-up of Gondwana allows an easier dispersion of the heat flow underneath Africa-Arabia with the subsequent reduction of the mean altitude and correlatively of the erosion), whereas the incipient orogens provide huge quantities of clasts;

2. the North Peri-Tethyan platform and east-west basinal alignment separated by structural highs are the seat of intense sedimentation whose characters depend on:

- marine global stand (transgression vs. regression);

- seaways connecting the main east-west basins and/or boreal or Tethyan oceans;

3. the progressive closing of the east-west Tethys seaway, which modifies the global oceanic current system (dynamic, temperature, geochemical composition, biology...);

4. a general northward cratonic kinematics, obvious for NE AfricaArabia, displaces the studied areas across the latitudinal climatic zones e.g., (Figure 6):

- in Arabia, the northern part of the Arab-Persian Gulf is located at $2^{\circ} \mathrm{N}$ in the Cenomanian, $7^{\circ} \mathrm{N}$ in the Maastrichtian, $19^{\circ} \mathrm{N}$ in the Lutetian, $25^{\circ} \mathrm{N}$ in the Langhian;

- in NW Africa (Agadir), the areas cross from $19^{\circ} \mathrm{N}$ in the Cenomanian, to $24^{\circ} \mathrm{N}$ in the Langhian;

- in Central Crimea, the sites go from $34^{\circ} \mathrm{N}$ in the Cenomanian to $43^{\circ} \mathrm{N}$ in the Langhian.

\section{Turbidites and palaeoenvironmental setting}

The most typical facies in Alpine times is a turbiditic regime with flysch and molasses. In this paper the term "flysch" is used when marine turbidites accumulate in a paleogeographical domain before its main tectonic phase takes place (i.e. the flysch deposits are conformable on the underlying deposits); the term "molasses" refers to the accumulation of marine, lacustrine or palustrine turbidites in a given palaeogeographic domain after an important tectonic event (i.e. the molasses deposits are unconformable on the underlying deposits) (Lorenz et al., 1993). The flysch basins are elongated (several thousands $\mathrm{km}$ long) and relatively narrow $(100 \mathrm{~km})$; they migrate in front of the belts, preceding them, and are mobile. Turbidites are characteristic neither of a particular palaeoenvironmental domain, nor of a specific depth, nor of the nature of the basement, but are rather indicative of the subsidence rate and space availability (e.g., the Late Cretaceous-Paleocene helminthoid flysch, located in front of the Northern Alps micro-plate, accumulates first on the Ligurian oceanic crust; then, during the Paleocene, due to reduction of space related to subduction, the flysch basin migrates on the continental crust in the Briançonnais zone; subsequently, in Rupelian times it migrates to the Dauphiné zone, and eventually it accumulates as molasses in a foreland basin during Langhian and Tortonian times).

Turbiditic flysch and molasses accumulate in marine or brackish waters (fluctuating salinity). These predominant deposits in the east-west alignment of basins are constitutive of the Para-Tethys in the Northern Peri-Tethyan platform and in the seaway connecting the Para-Tethys complex domain with Boreal, Tethyan or Mediterranean open seas. The high subsidence rate results in abundant lacustrine deposits alternating with evaporites and marine deposits in temperate climatic zones. The heat flow values and tectonic activity vary from medium to low. All these features generate rich petroleum systems (e.g., Vienna, Precaspian basins and Black and Caspian Seas in Rupelian time).

\section{Epicontinental deposits}

The shallow environment with fluctuating salinity is mainly carbonate during Cretaceous, Paleocene and Eocene times, occurring when turbidites accumulate in marine environments and only fine argillaceous sediments reach the continental margins, since the cratons are minor detritic suppliers. An exception to these established general conditions appears in both the Iberian and French cratons, where the 
Pyrenees range is emerging and clastic sediments accumulate on the bordering cratons.

Shallow marine carbonate deposits are significantly reduced in Alpine times. The northern Peri-Tethys domains cross the Tropic of Cancer, mean water temperature decreases as a consequence of a slower global spreading rate, and, correlatively, the greenhouse effect lessens. Moreover, the opening of seaways connecting Tethys and Boreal waters enhances the decrease of water temperature. Shallow carbonate deposits concentrate on African-Arabian shores.

The hemipelagic marine environment is dominated by chalk in the Northern Peri-Tethyan platform and presents a spectacular development in Campanian times, from England to the Aral Lake. These deposits accumulated at 100 to $600 \mathrm{~m}$ water depth and by mass flow can reach very deep basins.
Deep oceanic basin sediments are reduced in Alpine Time; most are preexisting, some are recent (i.e. the Pamphylian basin to the north of Africa in the Cenomanian is filled by sediments, as are the three Black Sea sub-basins which are marginal seas since Cenomanian times). Deep-sea sediments are defined here according to biological criteria not broadly accepted by all palaeobiologists.

Evaporite deposits are found in epicontinental terrigenous domains, like during Tethyan times, although in the Late Miocene huge accumulation occurred in the entire Mediterranean basin when both sea gates were closed (Arabian/Iranian and Gibraltar gates).

\section{Structural evolution}

From the Cenomanian onward, tectogenesis and orogenesis create the Alpine orogens. Data on the Tethys oceanic domains were presented previously (Dercourt et al., 1993). In the Peri-Tethys Atlas we

\section{LATE CENOMANIAN 94.7-93.5 Ma}

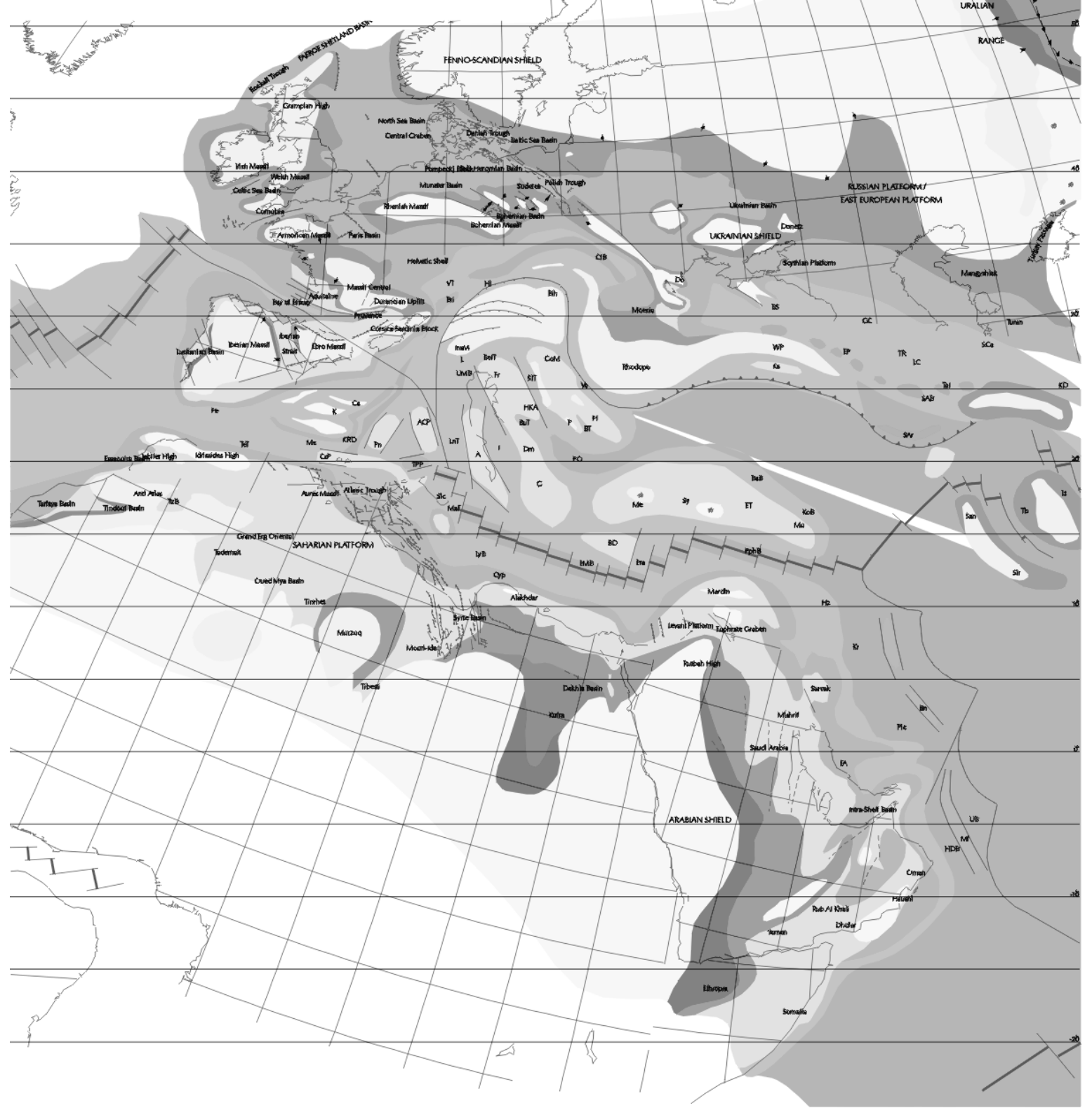

Figure 7 Simplified paleogeographic map of late Cenomanian time. 
illustrated the consequences of the Tethyan ocean and margins evolution and the subsequent response of the Peri-Tethyan platforms.

The Cenomanian is a key map in the Peri-Tethys Atlas (Figure 7). At the end of Tethyan Time, the extension is still active and an incipient compression marks the beginning of the Alpine Time, accompanied by:

1. a prevailing extension in the North Atlantic Ocean, associated with the development of oceanic basins (e.g., Bay of Biscay, Pamphylian and intra-Iranian cratonic basins), as well as in the Africa-Arabia craton (e.g., Tunisia, Egypt, North Arabia ensialic basins);

2. a compression affecting old oceanic basements of the northernmost micro-plate in the Mediterranean Seuil (e.g., Internal Alps) and folding appearing (Western Approaches, Celtic Sea, North Sea basins) in the northern cratonic Peri-Tethys (e.g., Rhenish, Bohemian, Sudetes massifs becoming coalescent by fault inversions).

Since the Maastrichtian, compression dominates

1. by involvement of the Mediterranean Seuil micro-plates, while in the north and south Peri-Tethyan platforms fault inversion results in folding (Laramian phase), and
2. by multiplication of subduction zones in the southern rim of all micro-plates present between the East European platform and the Africa-Arabia plate (Mediterranean Seuil).

During Lutetian times the collision continues (Figure 8). All the Mediterranean Seuil micro-cratons are thrust northwards on the thinned European craton (south-west of the Teisseyre-Tornquist permanent line) and transtensional incipient basins develop (West European rift). On the thick East European craton, a string of sedimentary basins forms an east-west depression. The permanent oceanic multisubduction zone develops wide marginal seas (Black Sea, Great Caucasian, Caucasian basins). The former Cimmerian blocks resume collisional activity.

In Rupelian times, as a consequence of the continuing northsouth displacement (collision of the Iranian micro-plate and the easternmost Mediterranean Seuil micro-plate with the East European platform), the string of east-west basins shaped inside the East European platform incorporates the Black Sea and Caspian basins in an unique sedimentary domain. A new feature appears in the form of a triple rift junction that affects the Africa-Arabia craton. A northsouth branch generates an incipient Red Sea, while the northwest-

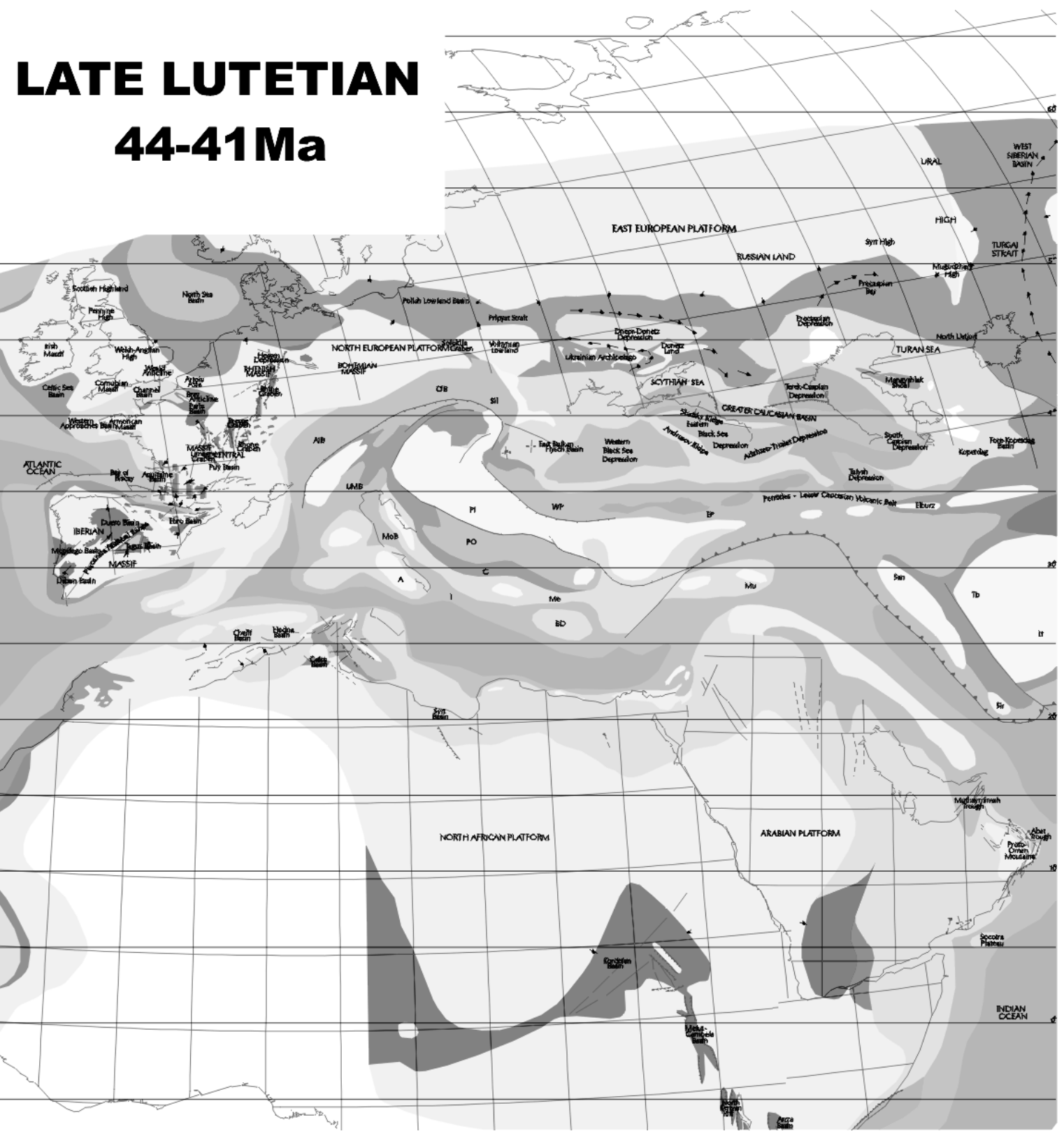

Figure 8 Simplified paleogeographic map of late Lutetian time. 
southeast branch generates an incipient Gulf of Aden and a rift system well expressed in the Djibouti Gulf. As a result, a brand new Arabian plate is formed. The three different branches were part of the Tethys time history since they have been controlling the sedimentary domain since the Callovian. A new subduction of the oceanic basin begins with parts of the Mediterranean Seuil subducting underneath the Iberian-French craton sealed by the Pyrenees, and creating the new Algeria-Provence oceanic marginal sea .

From Burdigalian times onward, the West and Central European Alpine mountain chains (southwest of the Teisseyre-Tornquist line) emerge and are eroded, thus feeding fluvio-lacustrine clastic basins; east-west structural elements dominate to the northeast of the Teisseyre-Tornquist line. The Caucasian range follows the same trend (folds and southward vergence nappes). The Turkish block of Mediterranean Seuil origin and the Iranian of Cimmerian origin participate in the Caucasian tectogenesis. The thrust of the Iranian Zagros domain on the Arabian micro-plate closes the east-west Tethys seaway, in existence since Callovian times (Figure 9).

During the Piacenzian, the same collisional trend continues. The collision between Iberia and Africa closes the western gate of the east-west Tethys Sea. In an isolated form and under open sea influence, the repeatedly desiccation of the Mediterranean leads to Messinian salt accumulation and the resulting diapirism both in deep-sea basins and on their margins.

\section{Magmatism}

Intense submarine magmatic activity accompanies the creation of oceanic basins. During Alpine Time this activity was moderate. With subduction being a major geodynamic process, andesitic flows are abundant in numerous accreted plates to the East European platform and relatively scarce in the arcs related to the subducting oceanic crust, including the Mediterranean Seuil (the present-day Stromboli or the few volcanoes of the Aegean arc-e.g. Santorini volcano-are examples of this localized activity).

Intra-plate volcanism (mainly alkaline) occurs when rifting systems affect the carbonatic area (e.g., West European rift).

A major volcanic system (hot spot) still highly active nowadays, isolates the Arabian from the African plate since Rupelian times.

\section{Pending problems}

When we started the Peri-Tethys Programme, the basic idea concerning the kinematic was to simply use the model of the previous Tethys Project (Dercourt et al., 1993). However, for the Pangea Time this assumption seems not to be always viable. We list here some of the questions still open:

\section{LATE TORTONIAN 8-7 Ma}

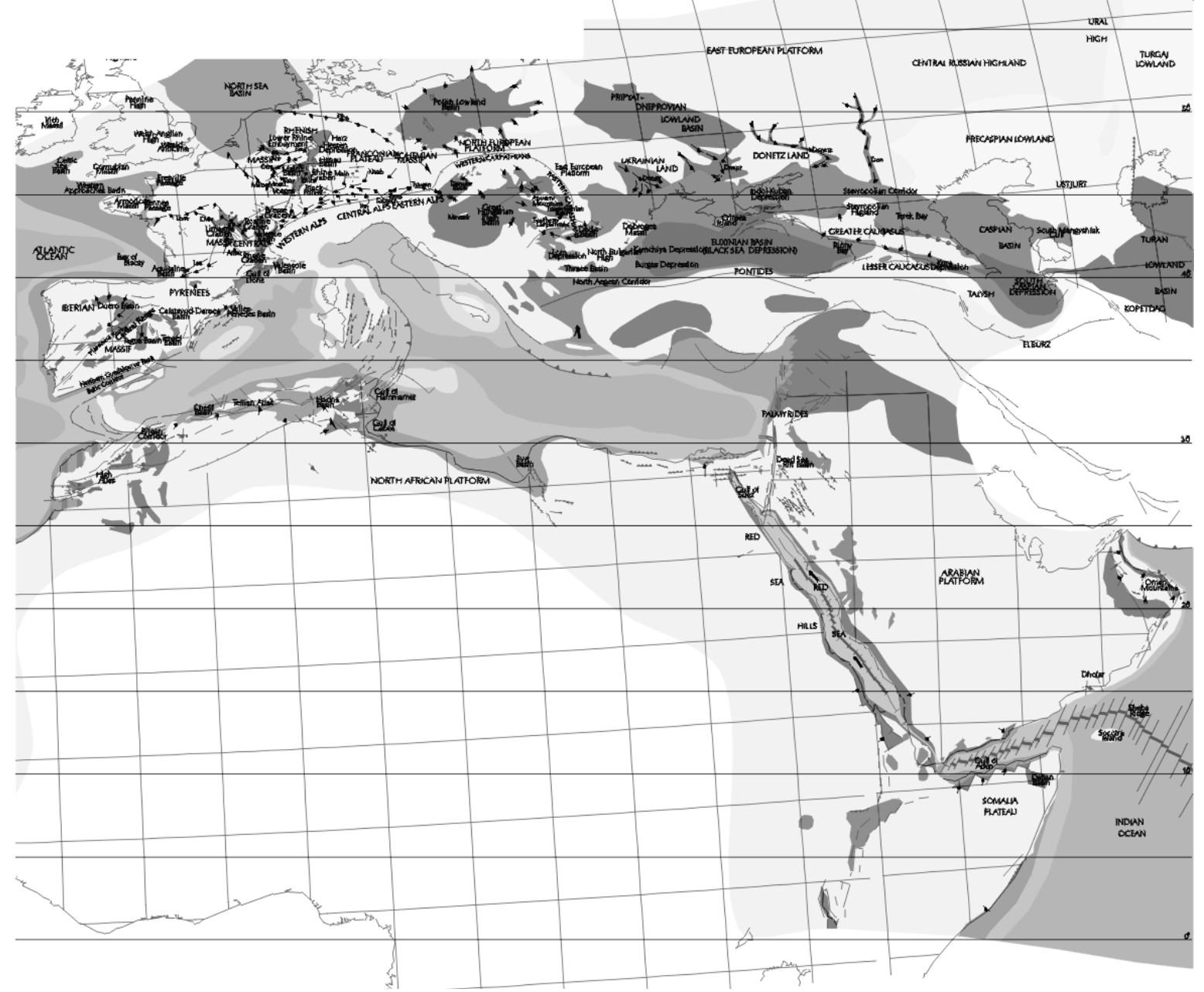

Figure 9 Simplified paleogeographic map of late Tortonian time. 
1. The two oldest time slices, Moscovian and Artinskian, were not studied in the Tethys Project. As a consequence we were faced with the problem of the Pangea configuration. This topic, which was largely beyond the scope of the Peri-Tethys Programme, was discussed earlier. However, two partially different interpretations were proposed for the future Mediterranean area. According to Vai \& Izart (2000), responsible for the Moscovian and Artinskian maps, the collision between Africa and Laurussia left open some connections between Panthalassa and Tethys during the Moscovian. Moreover, according to these authors, the propagation of the Neo-Tethys opening during the Artinskian was so advanced that not only the Pamphylian Through was already an oceanic seaway and consequently already fairly strongly rotated towards the northeast, but also this propagation was so advanced to put the Ionian Sea already in oceanic conditions during the Permian. This extreme propagation model was not followed by the other map leaders and by the Board of the Programme, because the oceanisation of the Ionian Sea seems to be more a Jurassic-Cretaceous event (Catalano et al., 2001). For this reason this area is left blank in the Artinskian map.

2. New field evidence from various states of the former Soviet Union gave new hints to the understanding of areas like Caucasus, Precaspian Basin and Turan. Also new data for the interpretation of Dobrogea and Moesia were obtained since the Tethys Project (Dercourt et al., 1993). We considered that the Tethyan oceanic floor, because it was expanding towards NE, underwent oblique subduction under the Eurasian margin, involving therefore also lateral displacements along the active margin and its back arc. This configuration is thought to be important for the
Caucasus and Turan (Garzanti and Gaetani, 2002; Gaetani et al., 2003). This interpretation is partly in contrast with what has been proposed in several models by Nikishin et al. (1998a,b). We moved Moesia to the southeast to have sufficient room to link the Permian seaway in the middle of Moesia (Pana, 1997) and to accomodate the Middle Triassic paleolatitudes found by Muttoni et al. (2000) for the Pre-Balkans. It it derived that Dobrogea rocks formed in a fairly large basin with thinned crust during the Triassic. With the Cimmerian orogeny, Dobrogea started to rotate towards the East European Platform, originating the Norian Flysch. This anti-clockwise rotation allowed the opening during the Jurassic of the Nis-Trojan Basin to the west. This is also a larger departure from the Tethys Project, which involved a partly different interpretation of the Balkan Peninsula. However, to reconsider this topic was out of the scope of the project and the field work in that area impossible in the present political situation.

3. A reconsideration of the Anatolian part, not scheduled at the beginning of the Programme, led to a partly different interpretation of that area, namely the Kirshehir massif position. The absence of a conclusive evidence that an ophiolitic belt originally existed to the south of the Kirshehir massif led to put it on the northern margin of the Anatolian platform, with the Tethys ocean to the north of it during the Pangea Time. The problem is: how large was the Pamphylian Through, when did it opened and when did it become an oceanic seaway, separating the Anatolian Platform from the North Arabic Spur? Is its age Cenomanian or older?

4. The limits of the thin crustal West European-Mediterranean Seuil domain. The northern limit is well established. The Teisseyre-

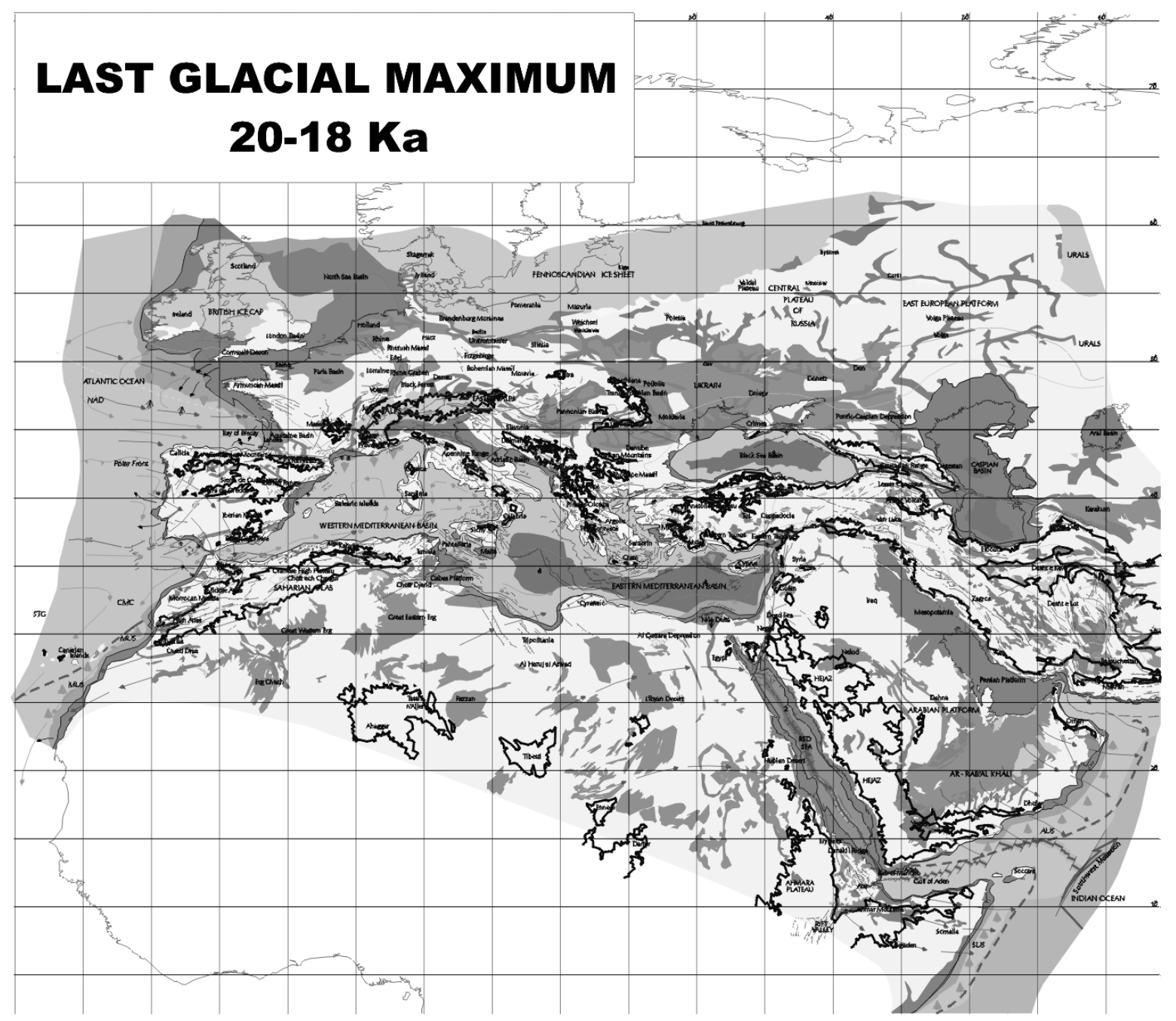

Figure 10 Simplified paleogeographic map of Last Glacial Maximum time. 
Tornquist line-a coherent set of vertical faults-crosses the North Sea, the Polish Trough, the Carpathian flysch basin (from which the sediments have been ejected and are now the outer Carpathian flysch nappes) and Dobrogea. A strong difference in lithospheric thickness exists along this "line", i.e. a thick lithosphere under the Eastern European Platform as far as the Urals chain vs. a thinner lithosphere under Central and Western Europe.

The southern limit has never been directly evidenced. In this Atlas it is suggested as a major limit between the African and Mediterranean lithospheres. Bayonet shaped, a long segment fringes the Maghreb, a short one lies along the Eastern Tunisian coast and another long segment borders the Libyan and Egyptian coasts.

5. Continental deposits on the platforms. The coastline delimiting continental from epicontinental deposits cannot be traced on our maps because these two types of deposits are usually deeply eroded at every regression stage. This is actually a major problem arising with any palaeoclimatic consideration when the extension of the sea acts as a climatic parameter.

\section{Conclusions}

The Peri-Tethys Programme was a successful scientific project involving hundreds of scientists from Europe, Africa and Asia. International cooperation was enhanced during the Programme. The detailed palaeogeographic and paleotectonic picture obtained from the Moscovian to Pleistocene (Figure 10) is new and provides researchers, petroleum geologists, paleobiogeographers and students of the past with a setting in which to place their results. We are aware of the problems still pending that contribute to make the palaeogeographic research fascinating, but we hope that this contribution brings broad and significant progress in the understanding of the evolution of western Tethys and its neighbouring areas.

\section{Acknowledgments}

We are very grateful to all the hundreds of scientists who worked in the Peri-Tethys Programme. Particularly we are indebted to the friends of the Board of the Programme, who shared with us this six year long adventure. In this review we largely used the Explanatory Notes of the Atlas and therefore we acknowledge their authorship.

\section{References}

Al Belushi, J. D., 1996, Permo-Carboniferous Glaciogenic Al Khlata Formation, Oman: A New Hypothesis for Origin of its Glaciation. Geoarabia, 1, 3, pp. 389-403.

Angiolini, L., 2001, Middle Permian Brachiopods from Oman and Perigondwanan correlations. In press: The systematic association volumes, Sp. Ser., in press.

Angiolini, L., Balini, M., Broutin, J., Crasquin-Soleau, S., Garzanti, E., Nicora, A., Platel, J. P., Roger, J., and Tintori, A., 2001, Lower to Middle Permian sedimentation on the Arabian Platform: the succession of the Haushi-Huqf area (Interior Oman). Guide-book to Excursion A02, Intern. Conf. Geology of Oman, Interior Oman, 7/1/01-11/1/01.

Besse J., Torcq, F., Gallet, Y., Ricou, L. E., Krystyn, L., and Saidi, A., 1998, Late Permian to Late Triassic palaeomagnetic data from Iran: constraints on the migration of the Iranian block through the Tethyan Ocean and initial destruction of Pangea, 135, pp. 77-92.

Catalano, R., Doglioni, C., and Merlini, A., 2001, On the Mesozoic Ionian basin. Geophysical Journal International, 144, pp. 49-64.

Courel, L., Ait Salem, H., Ben Ismail, H., El Mostaine, M., Fekirine, B., Kamoun, F., Mami, L., Oujidi, M. and Soussi, M.,2000, An overview of the epicontinental Triassic series of the Maghreb (NW Africa). Zentralblatt für Geologie und Paläontologie, Teil I, 1998, 9-10, pp. 1145-1166.

Dercourt, J., Ricou, L. E., and Vrielynck, B., 1993, Atlas Tethys palaeoenvironmental maps. 14 maps, 307 pp., Gauthier-Villars, Paris.
Gaetani, M., Garzanti, E., Polino, R., Kiricko, Y., Korsakhov, S., Cirilli, S., Nicora, A., Rettori, R., Larghi, C., and Bucefalo Palliani, R., 2003, Cimmerian orogenic events in NW Caucasus (Russia). Bulletin Societé Géologique de France, (submitted).

Gaetani, M., Arche, A., Kiersnowski, H., Chuvachov, B., Crasquin, S., Sandulescu, M., Seghedi, A., Zagorchev, I., Poisson, A., Hirsch, F., Vaslet, D., Le Metour, J. , Ziegler, M., Abbate, E., Ait-Brahim, L., Barrier, E. Bouaziz, S., Bergerat, F., Brunet, M.F., Cadet, J. P., Stephenson, R., Guezou, J. C., Jabaloy, A., Lepvrier, C., and Rimmele, G. ,2000, Wordian paleogeographic map. in Dercourt J., Gaetani M. \& et al. eds, Peri-Tethys Atlas and Explanatory notes, map 3, pp. 19-25, CCGM/CGMW, Paris.

Garzanti, E., Angiolini, L., and Sciunnach, D., 1996, The mid-Carboniferous to lowermost Permian succession of Spiti (Po Group and Ganmachidam Fm.; Tethys Himalaya, Northern India): Gondwana glaciation and rifting of Neo-Tethys. Geodinamica Acta, 9, pp. 78-100.

Garzanti, E., and Gaetani, M., 2002, Unroofing history of Late Paleozoic magmatic arcs within the "Turan Plate" (Tuarkyr, Turkmenistan). Sedimentary Geology.

Kent, D. V., Olsen, P. E., and Witte, W. K., 1995, Late Triassic-Early Jurassic geomagnetic polarity and paleolatitudes from drill cores in the Newark rift basin (Eastern North America). Journal Geophysical Research, 100 (B8), pp. 14.965-14.998.

Irving, E., 1977, Drift of the major continental blocks since the Devonian. Nature, 270, pp. 304-309.

Lorenz, C., Butterlin, J., Cavelier, C., Clermonte, J., Colchen, M., Dercourt, J., Guiraud, R., Montenat, C., Poisson, A., Ricou, L. E., and Sandulescu, M., 1993, Late Rupelian. in Dercourt, J., Ricou, L. E., and Vrielynck, B. Atlas Tethys Palaeoenvironmental maps. Explanatory Notes. Gauthiers Villars, pp. 211-224, Paris.

Marzoli, A., Renne, P. R., Piccirillo, E. M., Ernesto, M., Bellieni, G. and De Min, A., 1999, Extensive 200-Million-Year-Old Continental Flood Basalts of the Central Atlantici Magmatic Province. Science, 284, pp. 616-618.

Matte, Ph., 1996, La chaine varisique parmi les chaines paléozoiques périatlantiques, modèle d'évolution et position des grandes blocks continentaux au Permo-Carbonifère. Bulletin de la Société géologique de France, $8(2,1)$, pp. $9-24$.

Morel, P., and Irving, E., 1981, Paleomagnetism and the evolution of Pangea. Journal of Geophysical Research, 86, pp. 1858-1987.

Muttoni, G., Kent, D., and Channel, J., 1996, The evolution of Pangea: paleomagnetic constraints from the Southern Alps, Italy. Earth and Planetary Science Letters, 140, pp. 97-112.

Muttoni, G., Gaetani, M., Budurov, K., Zagorchev, I., Trifonova, E. Ivanova, D., Petrounova, L., and Lowrie, W., 2000, Middle Triassic palaoemagnetic data from Northern Bulgaria: Constraints on Tethyan magnetostratigraphy and palaeogeography, Palaeogeography, Palaeoclimatology, Paleoecology, 160,3, pp. 223-237.

Nikishin, A. M., Cloetingh, S. A. P. L., Bolotov, S. N., Baraboshkin, E. Y., F., Ershov, A. V., Ilina, V. V., Kosova, S. S., and Stephenson, R. A., 1998a, Scythian Platform: chronostratigraphy and polyphase stages of tectonic history. in S. Crasquin-Soleau, E. Barrier, eds., Peri-Tethys Memoir 3: Epicratonic basins of Peri-Tethyan platforms, 177, pp. 35-44.

Nikishin, A. M., Cloetingh, S., Brunet, M. F., Stephenson, R., Bolotov, S. N., and Ershov, A. V., 1998b, Scythian Platform, Caucasus and Black Sea region: Mesozoic-Cenozoic tectonic history and dynamics. in CrasquinSoleau, S., Barrier, E., eds, Peri-Tethys Memoir 3: Epicratonic basins of Peri-Tethyan platforms, Mémoires Museum national Histoire Naturelle, 177, pp. 163-176.

Olsen, P. E., 1999, Giant Lava Flows, Mass Extinctions, and Mantle Plumes. Science, 284, pp. 604-605.

Pana, C., 1997, Studiul biostratigrafic si paleoecologic al formatiunilor Paleozoice superioare din Platforma Moesica. Ph. D. Thesis, Univ. Bucuresti.

Ricou, L. E., 1993, Quelques élements remarquables de l'organisation des plaques. Comtes Rendu de l'Academie des Sciences. 316, pp. 1797-1804.

Ricou, L. E., 1996, The Plate Tectonic History of the Past Tethys Ocean. in Nairn, A. E. M., Ricou, L. E., Vrielynck B., and Dercourt, J., eds, The Ocean Basins and Margins. The Tethys Ocean. Plenum Press, New York, pp. 3-70.

Scotese, C. R., and McKerrow, W. S., 1990, Revised World maps and introduction. Palaeogeography and Biogeography. Geological Society of America, Memoires, 12, pp. 1-21.

Stampfli, G.M., 2000, Tethyan Oceans. in Bozkurt, E., Winchester, J. A., and Piper, J. D. A., eds, Tectonics and Magmatism in Turkey and the Surrounding Area. Geological Society of London, Special Publications, 173 pp. 1-23.

Torcq F., Besse J., Vaslet D., Marcoux J., Ricou L. E., Halawani M., and Basahel M., 1997, Paleomagnetic results from Saudi Arabia and the 
Permo-Triassic Pangea configuration. Earth and Planetary Sciences Letters, 148 , pp. 553-567.

Vai, G. B., Izart, A., Broutin, J., Chuvachov, B. I., and Vaslet, D., 2000, Artinskian paleogeographic map. in Dercourt J., Gaetani M. \& et al. eds, Peri-Tethys Atlas and Explanatory notes, map 2, 11-18, CCGM/CGMW, Paris

Vrielynck, B., Dercourt, J., and Cotterau, N., 1996, The Tethys: an ocean broken by seuils lithospheriques. in Nairn, A. E. M., Ricou, L. E., Vrielynck, B., and Dercourt, J. The Ocean Basins and Margins, v. 8: The Tethys Ocean, pp. 495-511, Plenum Press, New York.

Ziegler, A. M., 1983, Mesozoic and Cenozoic paleogeographic maps. in Brosche P., and Sundermann J., eds, Tidal Friction and the Earth's Rotation II. Springer-Verlag,, pp. 240-252.

\section{Peri-Tethys Special Publications}

\section{Peri-Tethys Memoirs}

Roure, F., Ed, 1994, Peri-Tethyan Platforms. 275 pp., Ed. Technip, Paris.

Ziegler P. A., and Horvath, F., eds, 1996, Structure and Prospects of Alpine Basins and Forelands. Mémoires du Museum national d'Histoire Naturelle, 170, 550 pp. + Atlas, Paris.

Crasquin-Soleau, S., and Barrier, E., eds, 1998, Stratigraphy and Evolution of Peri-Tethyan Platforms. Mémoires du Museum national d'Histoire Naturelle, 177, 262 pp., Paris.

Crasquin-Soleau, S., and Barrier, E., eds, 1998, Epicratonic Basins of PeriTethyan Platforms. Mémoires du Museum national d'Histoire Naturelle, 179, 294 pp., Paris.

Crasquin-Soleau, S., and Barrier, E., eds, 2000, New data on Peri-Tethyan Sedimentary Basins. Mémoires du Museum national d'Histoire Naturelle, 182, 266 pp., Paris.

Ziegler, P. A., Cavazza, W., Robertson, A. H. F., and Crasquin-Soleau, S., eds, 2001, Peri-Tethyan Rift/Wrench Basins and Passive margins. Mémoires du Museum national d'Histoire Naturelle, 186,762 pp., Paris.

\section{Geodiversities}

Crasquin-Soleau, S., and De Wever, P., eds, 1997, Peri-Tethys stratigraphic correlations 1. Geodiversitas, 19, 2, pp.169-499.

Crasquin-Soleau, S., and De Wever, P., eds, 1998, Peri-Tethys stratigraphic correlations 2. Geodiversitas, 20, 4, pp. 519-735.

Crasquin-Soleau, S., and De Wever, P., eds, 1999, Peri-Tethys stratigraphic correlations 3. Geodiversitas, 21, 3, pp. 289-493.

\section{Special issue on Elsevier journals}

Barrier, E., Bergerat, F., Angelier, J., Granath, J.W. ,eds, 2002, Paleostress and tectonics in the Peri-Tethyan margins. (Peri-Tethys Programme). Tectonophysics, 357, 1-4.

Brunet, M. F., Cloetingh, S., eds , 2002, Integrated Peri-Tethyan basin studies (Peri-Tethys Programme). Sedimentary Geology, 156, 1-4.

Gaetani, M., ed, 2003, Peri-Tethyan palaeogeography. Palaeogeography, Palaeoclimatology, Palaeoecology, in press..
Maurizio Gaetani is Professor of Geology at the University of Milan, Italy. His main interests are in the stratigraphy and paleogeography of the Permian and Triassic of the Tethys and Peri-Tethys, mainly in the areas of Eastern Mediterranean and Central Asia.

Jean Dercourt, Professor, P.M. Curie University, Paris, France. Stratigraphy, Tectonic, Paleogeography. Specialisation: Eastern Mediterranean and Western Canada domains. Tethyion and peritethyon platforms. Member of French Academie des sciences. Member of Academia Europaea.

Bruno Vrielynck is a Research Scientist at CNRS, Pierre \& Marie Curie University (UPMC) in Paris, France. He has a PhD in Structural Geology (1978) from Lille University and a HDR in Biostratigraphy (1984) from Lyon University. One of the first users of databases for the biostratigraphical research, he had experiences for managing the SIG databases needed for the Atlas Tethys and Peri-Tethys programs. $\mathrm{He}$ has developed software to manage the Kinematics in the SIG systems. He is now working in the Tectonics laboratory of UPMC and his research are focused on palaeogeography, tectonics and climate.
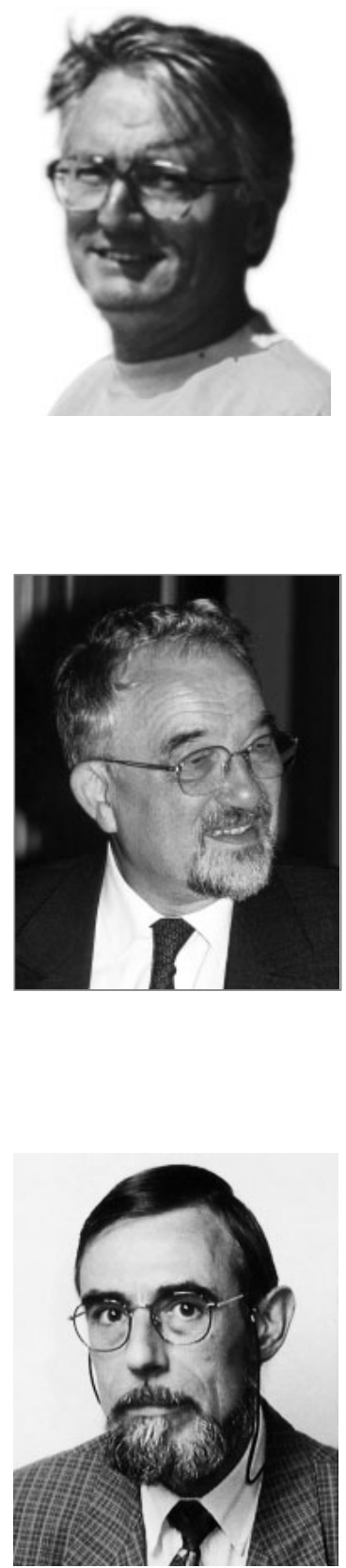